\title{
INITIAL EXPERIENCE OF ENDOSCOPIC SUBMUCOSAL DISSECTION IN BRAZIL TO TREAT EARLY GASTRIC AND ESOPHAGHEAL CANCER: a multi-institutional analysis
}

\author{
Dalton Marques CHAVES ${ }^{1}$, Eduardo Guimarães H. MOURA', \\ Daniela MILHOMEM ${ }^{2}$, Vitor N. ARANTES ${ }^{3}$, Kendi YAMAZAKI ${ }^{1}$, \\ Fauze MALUF ${ }^{5}$, Walton ALBUQUERQUE ${ }^{3}$, Antonio Carlos C. CONRADO ${ }^{4}$, \\ Júlia C. ARAÚJO ${ }^{4}$, Paula H. S. UEJO ${ }^{3}$ and Paulo SAKAI ${ }^{1}$
}

ABSTRACT - Objective - This study aimed to evaluate the feasibility and clinicopathological characteristics of early gastric and esophageal cancers treated with endoscopic submucosal dissection (ESD) at five centers in Brazil. Methods - Five centers in Brazil reported their initial experience with ESD. The cases reported had already been collected by each center before pooled analysis. Results - Were resected 62 gastric lesions; $52(83,8 \%)$ of the gastric lesions were well-differentiated adenocarcinoma, 31(50\%) from the antrum, 24 $(38.7 \%)$ type IIa. $51(82.2 \%)$ lesions had en-block resection with three showing lateral margin compromise. Concerning invasion, 25 $(40.3 \%)$ tumors were M1. Mean tumor diameter was $18.9 \mathrm{~mm}$ (range, 0.6-5.0 cm) and mean procedure duration was $119.45 \mathrm{~min}-$ utes. Gastric perforation occurred in three (4.8\%) patients. Mean follow-up duration was 11.3 months, with two local recurrences and one death from pneumonia Seven months after treatment. Of the 16 esophageal lesions resected, 14 (87.4\%) were squamous cell carcinoma, $10(62.5 \%)$ were located proximally and 8 (50.0\%) type IIa. Mean tumor diameter was $23.8 \mathrm{~mm}$ (range, 6-60 mm). Thirteen $(81.2 \%)$ lesions had en-block resection with five cases of lateral margin compromise. Eight (50.0\%) lesions were M1. Mean procedure duration was 78 minutes (range, 20-150 min). Complications included pneumomediastinum in two (12.5\%) patients and stenosis in one (6.2\%). Mean duration of follow-up was 8.6 months, with no local recurrence despite the presence of lateral margin compromise. Conclusion - Different centers in Brazil feasibly perform ESD with a high success rate.

KEYWORDS - Stomach neoplasms. Esophageal neoplasms. Endoscopy, digestive system. Multicenter study.

\section{INTRODUCTION}

Since the first results of endoscopic submucosal dissection $(\mathrm{ESD})^{(2,5,10)}$ to treat early gastric cancer, its acceptance has been progressive in all the word. This technique allows en-bloc resection of lesions larger than $20 \mathrm{~mm}$, providing a high accuracy of histological analysis and a reduced recurrence rate ${ }^{(2,5)}$. The main limitations of ESD are its technical difficulty and higher rate of complications especially for beginners. Most studies on ESD come from Japanese experts.

In Brazil, ESD is not yet a common practice. Primarily due to technical difficulties of the method and low rates of gastric and esophageal cancer diagnosed at an early stage. For these reasons ESD has been restricted to tertiary referral centers. Recently, some reports of the European experience with ESD were published $^{(11)}$. No similar study has been performed in Latin American countries. The aim of this study is to describe the results and outcomes of initial experience with ESD from five medical referral centers in Brazil.

\section{METHODS}

Five medical referral centers pioneering the use of ESD in Brazil participated in this study. Each center had their own group of endoscopists trained in centers of Japan or under the supervision of experienced Japanese endoscopists in Brazil. Group members were asked to complete an observation sheet for all consecutive patients treated by ESD.

All lesions were previously diagnosed by endoscopic biopsy. If available, ecoendoscopy was done. Patients Gerais, ${ }^{4}$ Hospital da Restauração de Recife; ${ }^{5}$ Instituto do Câncer do Estado de São Paulo

Correspondence: Dr. Dalton M. Chaves. Gastrointestinal Endoscopy Unit, Hospital das Clínicas, São Paulo University Medical School - São Paulo/SP, Brazil. Av. Dr. Eneias de Carvalho Aguiar 255, Prédio dos ambulatórios, Piso 6, Sala 3 - 05403-900-São Paulo - SP-Brazil. E-mail: chavesdalton@gmail.com 
were informed in detail about the ESD procedure and other treatment options. Clinicopathological features evaluated were: gender, age, tumor size, tumor location, macroscopic type, procedure time, en-block resection, complications, depth of invasion, lateral margins compromised and histologic type.

ESD was performed under sedation with midazolam, fentanyl, and propofol with constant monitoring of cardiorespiratory function during the procedure or under general anesthesia depending on the clinical condition of the patient. Using a standard video endoscope with $2 \%$ Lugol's solution for the esophagus and $0.4 \%$ indigo carmine for the stomach, the location, macroscopic type, and lateral extent of the lesion were determined. The procedure followed the steps recommended by Japanese authors as follow: a) marking outside the lesion; b) submucosal injection to produce a submucosal cushioning effect and lift the lesion; c) surrounding incision outside the marking; d) submucosal dissection. A transparent cap was attached to the tip of the endoscope if necessary (Figure 1).

Some different submucosal solutions were employed, including isotonic saline, hyaluronic acid, hydroxypropylmethyl cellulose (HPMC), and 10\% mannitol. A small amount of indigo carmine was mixed in all solutions and injected with a 21-25 gauge injection needle. Circumferential incision and submucosal dissection were achieved with a variety of cutting
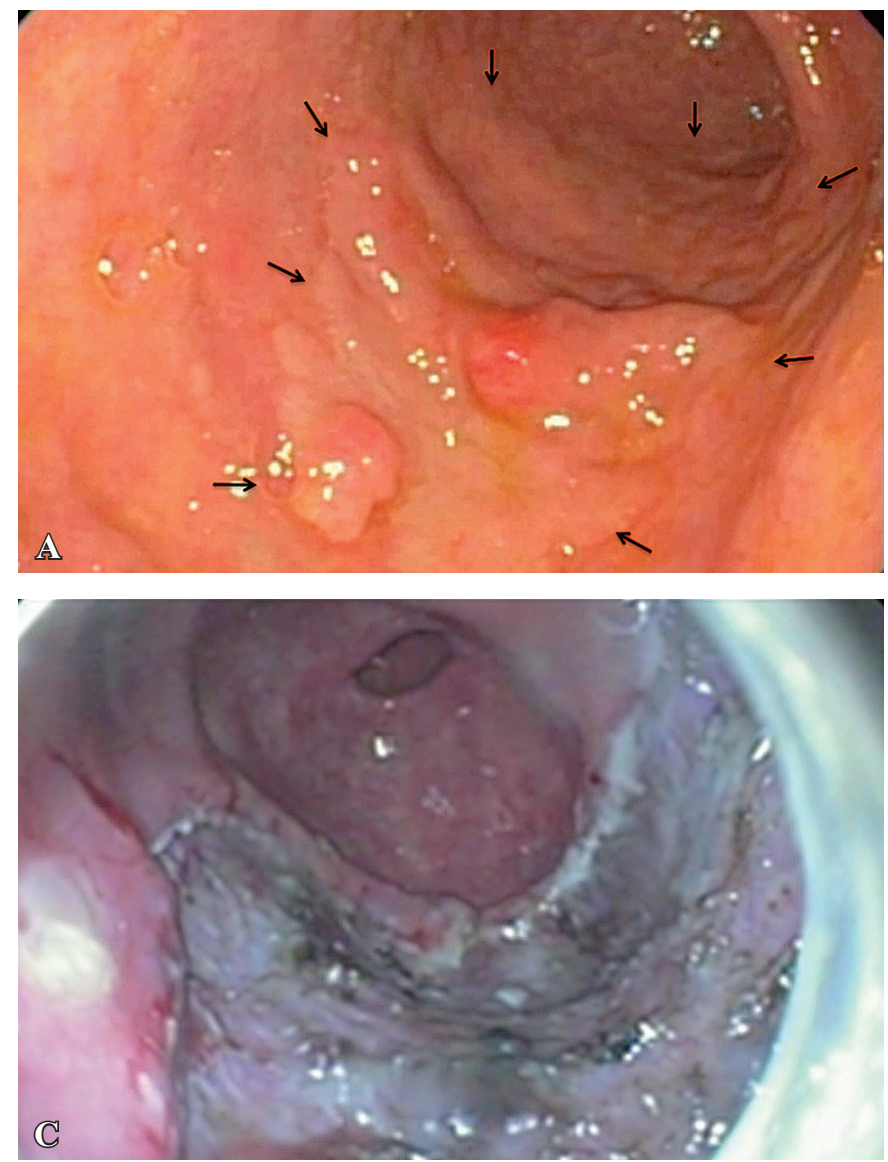

devices, including: IT-knife, Flex-knife, Needle-knife (Olympus Corp., Tokyo, Japan), and flush-knife (Fujinon Corp., Omiya, Japan). The use of one or any combination of these accessories was the choice of the endoscopist. Complications such as bleeding or perforations were immediately treated with hemostatic forceps or hemoclips. Remaining visible vessels after completed ESD were also coagulated routinely to prevent delayed bleeding.

For gastric lesions the indication and cure criteria were adopted according to the expanded criteria described by Gotoda et al. ${ }^{(4)}$. For esophageal lesions, the indication and cure criteria were: endoscopic signs of early lesion or ecoendoscopic examination confirming tumor limited to the mucosa or up to the superficial submucosa $(\mathrm{Sm} 1)$; histological confirmation of squamous cell carcinoma or high grade intraepithelial neoplasia restricted to the mucosa (M1 and M2); M3 lesions or those with Sm1 invasion without lymphatic and vascular involvement, superficial size less than 25 $\mathrm{mm}$; no signs of lymph node metastases ${ }^{(1)}$.

\section{RESULTS}

\section{Clinicopathological features}

From February 2004 to July 2009 a total of 78 lesions
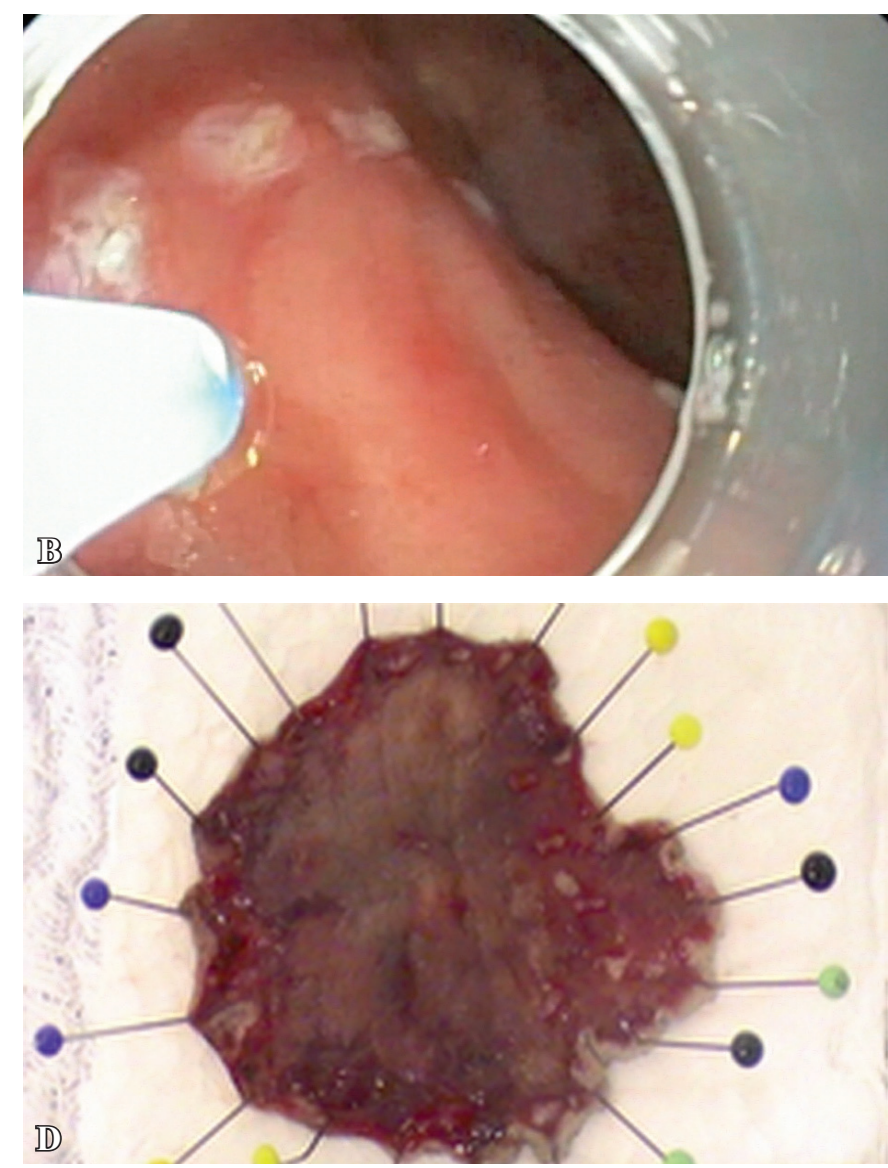

FIGURE 1A. Large gastric adenocarcinoma type IIa on the greater curvature of the antrum. B. Marking the lesion. C. Complete resection of the lesion. D. Resected specimen 
in 76 patients were treated by ESD. Sixty-two lesions were located in the stomach and 16 in the esophagus.

Mean age of patients with gastric lesions was 68 years (range, 32-83 years) and that for patients with esophageal lesions was 60.8 years (range, 48-83 years). Mean tumor size was $18.9 \mathrm{~mm}$ (range, $6-50 \mathrm{~mm}$ ) for gastric lesions and 23.8 $\mathrm{mm}$ (range, 6-60 $\mathrm{mm}$ ) for esophageal lesions.

Concerning location of gastric lesions, $31(50.0 \%)$ were in the antrum, $22(35.4 \%)$ in the body, $6(9.6 \%)$ in the cardia, and $3(0.5 \%)$ in the angular incisure. Of the 16 esophageal lesions, $10(62.5 \%)$ were located at the distal portion, $5(31.2 \%)$ at the mid portion, and $1(6.2 \%)$ at the upper esophagus. Tables 1 and 2 reports clinicopathological data.

TABLE 1. Clinical characteristics of patients

\begin{tabular}{|c|c|c|}
\hline & Gastric lesions & Esophageal lesions \\
\hline Patients/lesions & $61 / 62$ & $15 / 16$ \\
\hline Male $(\%)$, Female $(\%)$ & $33(54.0 \%), 28(46 \%)$ & $14(93.3 \%), 1(6.7 \%)$ \\
\hline Mean age (range) & $68(32-83)$ & $60.8(48-83)$ \\
\hline \multicolumn{3}{|l|}{ Location, $\mathrm{n}(\%)$} \\
\hline $\begin{array}{l}\text { Antrum, body, } \\
\text { cardia, incisure }\end{array}$ & $\begin{array}{c}31(50.0 \%), 22(35.4 \%) \\
6(9.6 \%), 3(5.0 \%)\end{array}$ & \\
\hline $\begin{array}{l}\text { Proximal, middle } \\
\text { Distal }\end{array}$ & & $\begin{array}{c}1(6.2 \%), 5(31.3 \%) \\
10(62.5 \%)\end{array}$ \\
\hline $\begin{array}{l}\text { Lesion size } \\
\text { median (range), } \mathrm{mm}\end{array}$ & $18.9(6-50)$ & $23.8(6-60)$ \\
\hline \multicolumn{3}{|l|}{ Macroscopictype, n(\%) } \\
\hline $\begin{array}{l}\text { IIa, IIb } \\
\text { IIc, IIa + IIc } \\
\text { IIb + IIc, not } \\
\text { classified }\end{array}$ & $\begin{array}{c}24(38.7 \%), 3(4.8 \%) \\
16(25.8 \%), 18(29.0 \%) \\
0(0 \%), 1(1.6 \%)\end{array}$ & $\begin{array}{l}2(12.5 \%), 8(50.0 \%) \\
1(6.2 \%), 2(12.5 \%) \\
2(12.5 \%), 1(6.2 \%)\end{array}$ \\
\hline $\begin{array}{l}\text { Procedure time, } \\
\text { median (range), min }\end{array}$ & $119.45(20-300)$ & $132.2(20-420)$ \\
\hline $\begin{array}{l}\text { En-block } \\
\text { resection, n (\%) }\end{array}$ & $51(82.2 \%)$ & $13(81.2 \%)$ \\
\hline \multicolumn{3}{|l|}{ Complications, $\mathrm{n}(\%)$} \\
\hline $\begin{array}{l}\text { Immediate bleeding } \\
\text { Delayed bleeding }\end{array}$ & $\begin{array}{l}0 \\
0\end{array}$ & $\begin{array}{l}0 \\
0\end{array}$ \\
\hline $\begin{array}{l}\text { Perforation } \\
\text { Pneumomediastinum } \\
\text { Stenosis }\end{array}$ & $\begin{array}{c}3(4.8 \%) \\
0 \\
0\end{array}$ & $\begin{array}{c}0 \\
2(12.5 \%) \\
1(6.2 \%)\end{array}$ \\
\hline Mortality, n (\%) & 0 & 0 \\
\hline
\end{tabular}

\section{Endoscopic devices and injection solutions}

The IT-knife was employed to remove $53(85.5 \%)$ gastric and $9(56.2 \%)$ esophageal lesions. The Flex-Knife was used for $4(6.5 \%)$ gastric and $4(25.0 \%)$ esophageal lesions; the Flush-Knife was employed for $5(8.0 \%)$ gastric and $3(18.8 \%)$ esophageal lesions. To lift the lesions, injection solutions included saline in $48(61.5 \%)$ cases, mannitol in $16(20.5 \%)$, HPMC in $10(12.8 \%)$, and sodium hyaluronate in $4(5.1 \%)$.

\section{Histologic assessment and macroscopic tumor type}

Of the 62 gastric lesions resected, $52(83.8 \%)$ were well differentiated adenocarcinoma, $3(4.8 \%)$ undifferentiated adenocarcinoma, $4(6.4 \%)$ adenoma, $1(1.6 \%)$ neuroendocrine neoplasia, $1(1.6 \%)$ metaplasia and $1(1.6 \%)$ hyperplasic lesion. Regarding macroscopic appearance, $24(38.7 \%)$ were type IIa, $3(4.8 \%)$ type IIb, $16(25.8 \%)$ type IIc, $18(29.0 \%)$ type IIa+IIc, and $1(1.6 \%)$ not classified.

Of the 16 esophageal lesions, $14(87.4 \%)$ were squamous cell carcinoma, and $2(12.5 \%)$ well differentiated adenocarcinoma. Regarding macroscopic type, $2(12.5 \%)$ were type IIa, $8(50.0 \%)$ type IIb, $1(6.2 \%)$ type IIc, $2(12.5 \%)$ type IIa +IIc, $2(12.5 \%)$ type IIb+IIc, and 1 (6.2\%) not classified.

\section{Outcomes}

En bloc resections were achieved for $51(82.2 \%)$ of the 62 gastric lesions. Three (4.8\%) of the en bloc resected tumors had lateral margin compromised. In two cases additional EMR was performed and the third case had submucosal invasion (Sm2) requiring surgical resection. As to the degree of invasion, $25(40.3 \%)$ were M1, $13(20.9 \%) \mathrm{M} 2,20(32.2 \%)$ M3, $3(4.8 \%)$ Sm1, and $1(1.6 \%)$ Sm2. All patients with Submcosal invasion underwent surgical treatment except for one patient, who was previously diagnosed with soft tissue sarcoma with multiple pulmonary metastases and referred to chemoteraphy. Median procedure time was 119.45 minutes (range, 20-300 $\mathrm{min}$ ).

Of the 16 esophageal lesions, $13(81.2 \%)$ were resected en bloc with $5(31.2 \%)$ having lateral margin compromise. Because of technical difficulties, three lesions were resected piece meal, making it difficult to analyze lateral margins.

TABLE 2. Histopathological characteristics of patients

\begin{tabular}{lcc}
\hline & Gastric lesions & Esophageal lesions \\
\hline Depht of invasion & & $8(50.0 \%), 3(18.7 \%)$ \\
M1 (\%), M2 (\%), & $25(40.3 \%), 13(20.9 \%)$ & $2(12.5 \%)$ \\
M3 (\%) & $20(32.2 \%)$ & $3(18.7 \%), 0(0 \%)$ \\
Sm1 (\%), Sm2 (\%) & $3(4.8 \%), 1(1.6 \%)$ & $5(31.2 \%)$ \\
Lateral margins & $3(4.8 \%)$ & $3(18.7 \%)$ \\
Compromised, N (\%) & 0 & $2(12.5 \%)$ \\
Not analyzed, N (\%) & $52(83.8 \%)$ & 0 \\
Histologic type, N (\%) & $3(4.8 \%)$ & $14(87.4 \%)$ \\
Well-differentiated adenocarcinoma & 0 & 0 \\
Undifferentiated adenocarcinoma & $4(6.4 \%)$ & 0 \\
Squamous cell carcinoma & $1(1.6 \%)$ & 0 \\
Adenoma & $1(1.6 \%)$ & 0 \\
Neuroendrocrine neoplasia & $1(1.6 \%)$ & \\
Metaplasia & & \\
Hyperplasic polyp & & \\
\hline
\end{tabular}


As to the degree of invasion, $8(50.0 \%)$ were M1, $3(18.7 \%)$ $\mathrm{M} 2,2(12.5 \%) \mathrm{M} 3$, and $3(18.7 \%) \mathrm{Sm} 1$. Median procedure time was 132.2 minutes (range, 20-420 min).

There were no deaths. Gastric perforation occurred in three $(4.8 \%)$ patients. None required surgical treatment; all were treated conservatively by endoscopic hemoclips, fasting, and intravenous antibiotics.

Complications with esophageal resections were pneumomediastinum in two $(12.5 \%)$ patients without evident perforation, diagnosed by $\mathrm{x}$-ray, both treated with intravenous antibiotics and fasting. One (62\%) patient developed stenosis and underwent endoscopic dilation.

\section{Follow-up}

Mean follow-up period for patients with gastric lesions was 11.3 months (range, 1-30 months) with two local recurrences and one death from pneumonia seven months after treatment. Two patients were found to have recurrent early gastric cancers during the follow-up period. One patient had two metachronous gastric lesions diagnosed 3 months after endoscopic resection; this patient was referred for surgical resection. The other patient was diagnosed one year after initial treatment, and underwent a second ESD. No recurrence was found at follow-up on year after the second ESD. Mean follow-up for the esophageal group was 8.6 months (range, 1-24 months) with no local recurrence despite the presence of lateral margin compromise.

\section{DISCUSSION}

The first live demonstration of ESD in Brazil aroused the interest of some endoscopic centers because of its expertise and advantageous results. The opportunity of exchanges with centers in Japan, were of the great importance to introducing ESD to Brazil ${ }^{(1)}$. ESD procedure duration and incidence of complication are directly related to the experience of the endoscopist.

Contrary to EMR, ESD allows large en-bloc resections contributing to better evaluation of resected specimens and consequently lower local recurrence rates. In this study, two cases were not confirmed malignant tumors after ESD. The procedure was important to discharge cancer in these cases.

The incidence of local recurrence after EMR procedures ranges from $2.3 \%$ to $36.5 \%$, whereas initial studies of ESD report recurrence rates of $0 \%$ to $1 \%{ }^{(4)}$.

As for en-bloc resection of gastric cancer, success rates for both techniques are similar for lesions smaller than $1 \mathrm{~cm}$ in diameter, being greater than $90 \%$. For lesions larger than $1 \mathrm{~cm}$, ESD still shows a success rate over $90 \%$, but EMR is successful in only half of the cases ${ }^{(14)}$. In the current study $82.2 \%$ of gastric lesions and $81.2 \%$ of esophageal lesions were removed en bloc. We considered a good rate for beginners. The expertise of the physicians involved in this study associated with proper training could explain this high rate of success.

The incidence of perforation with different EMR techniques ranges from $0 \%$ to $4.0 \%$, whereas with $\mathrm{ESD}$ the rate is $0 \%$ to $5.0 \%$. Comparing these methods, Watanabe et al. ${ }^{(14)}$ did not verify a statistical difference in the incidence of perforation, $3.2 \%$ for EMR and $4.2 \%$ for ESD. However, Oka et al. ${ }^{(9)}$ analyzed only nonulcerative lesions found an incidence of $0.5 \%$ for EMR and a $9.7 \%$ for EDS, which was statistically significant. In this study the rate of gastric perforation was $4,8 \%$, all treated without surgery. Two cases after esophageal ESD had pneumomediastinum, without perforation. This is a relatively common complication that usually had a good outcome.

Bleeding is one of the most common complications in endoscopic resections. Oka and colleagus ${ }^{(9)}$ verified that the incidence of bleeding during and after EMR was $7.6 \%$ and $3.9 \%$ for nonulcerative lesions; for ESD, rates were $22.6 \%$ and $6.2 \%$, respectively. The bleeding is related with the lesion size and location. The absence of later bleeding in this study may be explained by the few cases of big lesions, since the average size of the gastric lesions was $1,8 \mathrm{~cm}$. Lesions of the greater curvature also tends to bleed more, however we did not evaluate this data. The presence of lymph node metastasis is closely related to the degree of invasion into the esophageal and gastric wall. Esophageal lesions confined to the $\mathrm{m} 1$ and $\mathrm{m} 2$ layers do not present with lymph node metastasis. For deeper lesions Makuuchi $\mathrm{H}_{\left({ }^{(7)}\right.}$ reported the following incidence of metastasis: $\mathrm{m} 3$ (9.1\%), Sm1 (15.4\%), $\mathrm{Sm} 2(40.0 \%)$, and $\mathrm{Sm} 3(44.1 \%)$. In this study, three cases were Sm1; these patients did not undergo surgery because of poor clinical condition.

In the stomach, the incidence of lymph node metastasis is considered irrelevant for lesions confined to the mucosa $(\mathrm{m} 1$ and $\mathrm{m} 2$ ) 0 to $3 \%$. For lesions that invade the submucosa, the lymph node metastasis occurred from $9 \%$ to $19 \%{ }^{(6)}$.

In the past the Japanese Society of Gastric Cancer defined the following criteria for endoscopic resection ${ }^{(4,8,13)}$ of gastric cancer based on results for endoscopic treatment and on the incidence of lymph node metastasis: non ulcerated or healed lesions, differentiated (IIa and IIb) type lesions smaller than $2 \mathrm{~cm}$, and IIc type lesions smaller than $1 \mathrm{~cm}$. If a patient was not a surgical candidate, submucosal resection may be considered for lesions larger than $2 \mathrm{~cm}$ and for those invading up to Sm1. For undifferentiated tumors, several authors did not advise endoscopic treatment because of the diffuse growth common to these lesions. Clinical observations using previously discussed criteria for endoscopic resections demonstrate that a significant number of patients undergo surgery unnecessarily. Gotoda et al. ${ }^{(3)}$ analyzed data on more than 5,000 gastrectomies with D2 nodal dissections, defined the group at risk for lymph node metastasis, and expanded the criteria for endoscopic resection for gastric cancer by applying the ESD technique for: restricted to the mucosa differentiated nonulcerated lesions greater than $2 \mathrm{~cm}$, ulcerated lesions less than or equal to $3 \mathrm{~cm}$, and differentiated lesions with superficial submucosal invasion (Sm1) less than or equal to $3 \mathrm{~cm}^{(4,12)}$. These expanded criteria increase the number of patients eligible for endoscopic treatment for gastric lesions and contributed to the acceptance of ESD. 
In Brazil the ESD technique is becoming more widespread because of access to the necessary devices, particularly the IT-Knife and flush-knife, as well as training in live porcine models under supervision of Japanese experts. We believe that experimental training with experienced teachers is crucial for endoscopists beginning to use this technique. Some basic technical principles of each devise must be respected in order to achieve success.

Based on our results, we conclude that ESD has proven feasible in different Brazilian centers with a high success rate. However, we believe that this procedure should be reserved for experienced and trained endoscopists.

Chaves DM, Moura EGH, Milhomen D, Arantes VN, Yamazaki K, Maluf F, Albuquerque W, Conrado ACC, Araújo JC, Uejo PHS, Sakai P. Experiência inicial no Brasil da técnica de dissecção endoscópica da submucosa para tratamento do câncer precoce do estômago e esôfago: uma análise multi-institucional. Arq Gastroenterol. 2013,50(2):148-52.

RESUMO - Objectivo - Este estudo tem como objetivo avaliar a viabilidade da técnica de dissecção endoscópica da submucosa (DES) no tratamento do câncer precoce do estômago e do esôfago, assim como as características clinicopatológicas dos pacientes tratados em diferentes centros no Brasil. Métodos - Cinco centros no Brasil relataram sua experiência inicial com a técnica de DES. Os casos relatados vinham sendo coletados em cada serviço antes da análise agrupada dos dados. Resultados - Foram ressecadas 62 lesões gástricas, sedo 52 (83,8\%) adenocarcinoma bem diferenciado, 31 (50\%) localizadas no antro e 24 (38.7\%) do tipo macroscópico IIa. Foram ressecadas em monobloco 51 (82.2\%) lesões, com 3 apresentando margem lateral comprometida. Quanto ao grau de invasão, 25 (40.3\%) eram restritas ao epitélio da mucosa (M1). O diâmetro médio das lesões foi de 18.9 (6-50) mm, o tempo médio dos procedimentos foi de 119.45 minutos. A incidência de perfuração gástrica foi de 4,8\% (três casos). O tempo médio de seguimento foi de 11.3 meses, com duas recorrências locais e uma morte por pneumonia 7 meses após o tratamento. Das 16 lesões esofágicas ressecadas, 14 (87.4\%) eram carcinoma epidermóide, $10(62.5 \%)$ localizados na porção proximal, 8 (50.0\%) do tipo macroscópico IIa. O diâmetro médio das lesões foi de 23.8 (6-60) $\mathrm{mm}$. Foram ressecadas em monobloco 13 (81.2\%) lesões, sendo que 5 apresentaram margem lateral comprometida e 8 (50.0\%) com invasão restrita a camada epitelial (M1). A duração média dos procedimentos foi de 78 (20-150) minutos. Dois (12.5\%) pacientes tiveram pequeno pneumomediastino e um (6.2\%) evoluiu com estenose esofágica. O tempo médio de seguimento foi de 8.6 meses, sem recorrência local mesmo nos casos que apresentaram margem lateral comprometida pela histopatologia. Conclusão - A técnica de DES tem sido factível em diferentes centros do Brasil com alto índice de sucesso.

DESCRITORES - Neoplasias gástricas. Neoplasias esofágicas. Endoscopia do sistema digestório. Estudo multicêntrico.

\section{REFERENCES}

1. Chaves DM, Maluf Filho F, de Moura EG, Santos ME, Arrais LR, Kawaguti F Sakai P. Endoscopic submucosal dissection for the treatment of early esophageal and gastric cancer: initial experience of a western center. Clinics 2010;65:377-82.

2. Gotoda T, Kondo H, Ono H, Saito Y, Yamaguchi H, Saito D, Yokota T. A new endoscopic mucosal resection (EMR) procedure using a insulation-tipped diathermic (IT) knife for rectal flat lesions. Gastrointest Endosc. 1999;50:560-3.

3. Gotoda T, Yanagisawa A, Sasako M, Ono H, Nakanishi Y, Shimoda T, Kato Y. Incidence of lymph node metastasis from early gastric cancer: estimation with a large number of cases at two large centers. Gastric Cancer. 2000;3:219-25.

4. Gotoda T. Endoscopic resection of early gastric cancer. Gastric Cancer. 2007;10:1-11

5. Hosokawa K, Yoshida S. Recent advances in endoscopic mucosal resection for early gastric cancer. Gan To Kagaku Ryoho. 1998;25:476-83.

6. Kojima T, Parra-Blanco A, Takahashi H, Fujita R. Outcome of endoscopic mucosal resection for early gastric cancer: review of the Japanese literature. Gastrointest Endosc. 1998;48:550-4.

7. Makuuchi H. Endoscopic mucosal resection for early esophageal cancer: indications and techniques. Digestive Endoscopy. 1996;8:175-9.
8. Noda M, Kodama T, Atsumi M, Nakajima M, Sawai N, Kashima K, Pignatelli M. Possibilities and limitations of endoscopic resection for early gastric cancer. Endoscopy. 1997;29:361-5.

9. Oka S, Tanaka S, Kaneko I, Mouri R, Hirata M, Kawamura T, Yoshihara M, Chayama K. Advantage of endoscopic submucosal dissection compared with EMR for early gastric cancer. Gastrointest Endosc. 2006;64:877-83.

10. Ono H, Kondo H, Gotoda T, Shirao K, Yamaguchi H, Saito D, Hosokawa K, Shimoda T, Yoshida S. Endoscopic mucosal resection for treatment of early gastric cancer. Gut. 2001;48:225-9.

11. Probst A, Pommer B, Golger D, Anthuber M, Arnholdt H, Messmann H. Endoscopic submucosal dissection in gastric neoplasia - experience from a european center. Endoscopy. 2010;42:1037-1044.

12. Soetikno R, Kaltenbach T, Yeh R, Gotoda T. Endoscopic mucosal resection for early cancers of the upper gastrointestinal tract. J Clin Oncol. 2005;23:4490-8

13. Tada M, Murakami A, Karita M, Yanai H, Okita K. Endoscopic resection of early gastric cancer. Endosocopy. 1993;25:445-50.

14. Watanabe K, Ogata S, Kawazoe S, Watanabe K, Koyama T, Kajiwara T, Shimoda Y, Takase Y, Irie K, Mizuguchi M, Tsunada S, Iwakiri R, Fujimoto K. Clinical outcomes of EMR for gastric tumors: historical pilot evaluation between endoscopic submucosal dissection and conventional mucosal resection. Gastrointest Endosc. 2006;63:776-82 